\title{
Intertidal rocky shore seaweed communities subject to the influence of shallow water hydrothermal activity in São Miguel (Azores, Portugal)
}

\author{
Francisco M. Wallenstein - Ruben P. Couto • \\ Daniel F. Torrão • Ana I. Neto • \\ Armindo S. Rodrigues • Martin Wilkinson
}

Received: 26 September 2012/Revised: 7 November 2012/ Accepted: 9 November 2012/Published online: 24 November 2012

(C) Springer-Verlag Berlin Heidelberg and AWI 2012

\begin{abstract}
The volcanic origin of the Azores archipelago (Portugal) gives rise to active deep sea and shallow water hydrothermal activity that affects benthic communities. Intertidal seaweed surveys were conducted at two shores affected by intense shallow water hydrothermal vents. Water temperature, acidity and salinity were monitored. Seaweed communities were found to be species poor and have a disproportionally larger number of filamentous early
\end{abstract}

Communicated by H.-D. Franke.

F. M. Wallenstein · M. Wilkinson

Centre for Marine Biodiversity and Biotechnology,

School of Life Sciences, Heriot-Watt University,

Edinburgh EH14 4AS, Scotland, UK

e-mail: m.wilkinson@hw.ac.uk

F. M. Wallenstein $(\varangle) \cdot$ R. P. Couto · A. I. Neto ·

A. S. Rodrigues

CIRN \& Departamento de Biologia, Universidade dos Açores, 9501-801 Ponta Delgada, Açores, Portugal

e-mail: fwallenstein@uac.pt

R. P. Couto

e-mail: coutoruben@uac.pt

A. I. Neto

e-mail: aneto@uac.pt

A. S. Rodrigues

e-mail: rodrigues@uac.pt

F. M. Wallenstein $\cdot$ R. P. Couto $\cdot$ A. I. Neto

LAIR, CIIMAR, 4050-123 Porto, Portugal

D. F. Torrão

CIRN \& Departamento de Biologia, Universidade dos Açores, 4050-123 Porto, Portugal

e-mail: d.torrao@gmail.com

\section{A. S. Rodrigues}

CVARG, 9501-801 Ponta Delgada, Açores, Portugal successional species on shores that are subject to the effect of hot and acidic freshwater of volcanic origin. There is an ecological resemblance between hydrothermally affected seaweed communities in the Azores and those affected by acid mine drainage in the UK, thus indicating that hydrothermalism can be a useful scenario for pollution studies under conditions of ocean warming and acidification.

Keywords Intertidal $\cdot$ Macroalgae $\cdot$ Hydrothermal activity - Pollution

\section{Introduction}

The Azores islands are located in the northern Atlantic Ocean $\left(36^{\circ} \mathrm{N} / 31^{\circ} \mathrm{W}\right.$ and $43^{\circ} \mathrm{N} / 25^{\circ} \mathrm{W}$ ), and their recent volcanic origin is indicated by active deep sea and shallow water hydrothermal activity. Such habitats are naturally enriched in heavy metals (see Von Damm 1990; Carvalho et al. 2011) and thus provide examples of naturally polluted sites to compare with those that are affected by human pollution. They also provide unusual ecological situations of increased temperature and acidity due to the input of hot hydrothermal water springs and the diffusion of acidic volcanic gases (mainly $\mathrm{CO}_{2}$; Cruz and França 2006; Carvalho et al. 2011). Organisms that live in such environments are therefore chronically exposed to thermal pollution and chemical pollution as well as to acidification that can affect biotic communities at various levels (e.g., productivity, species diversity, abundance and composition, and the bioaccumulation of contaminants), consequently affecting overall ecosystem health (Elliott and Cutts 2004).

There have been studies on the effects of shallow water hydrothermal activity on subtidal marine organisms in the Mediterranean (e.g., Dando et al. 1991; Sartoni and De Biasi 1999; De Biasi and Aliani 2003; De Biasi et al. 2004) 
and in the Azores (Cardigos et al. 2005; Colaço et al. 2006). Intertidal organisms affected by such conditions were first addressed by Wallenstein et al. (2009) reporting increased accumulation of some heavy metals in seaweeds collected in the vicinity of hydrothermal venting near the shore, and by Couto et al. (2010) who reported effects on the structure of calcareous coralline algae due to hydrothermal conditions. However, there is no record of how intertidal community composition can be affected by hydrothermal activity.

The present study is a first account of the habitat characteristics and associated intertidal seaweed communities on two rocky shores subjected to shallow water hydrothermal activity in the Azores.

\section{Methods}

Location

Two shores (Ferraria and Porto Formoso, Fig. 1) subject to shallow water hydrothermal discharges were chosen for the purpose of the present study.

\section{Ferraria}

Ferraria (Fig. 2) is a bathing area located on the westernmost coast of São Miguel Island, attractive to tourists due to its warm sea water temperature at low tide. It is a semienclosed bay with an approximate surface area of $300 \mathrm{~m}^{2}$ and maximum depth of approximately 3-4 $\mathrm{m}$. The bay opens to the ocean through a south facing $3 \mathrm{~m}$ wide and $2 \mathrm{~m}$ deep aperture. On the eastern side of the embayment, close to land, an approximately $30 \mathrm{~m}$ stretch of shore is of basalt boulders that were placed there by the local authorities. On the opposite side of the bay, the shore consists of a vertical solid bedrock wall (also approximately $30 \mathrm{~m}$ in length). Ferraria is fairly sheltered from wave action given its south facing nature and the dominance of northern wave exposure throughout the archipelago (Hidrográfico 2000). The hydrothermal input is at the innermost end of the bay.

\section{Porto Formoso}

The survey site at Porto Formoso on the north coast of São Miguel Island (Fig. 1) is where the effect of hydrothermal activity can be observed at low tide along a stretch of shore of approximately $50 \mathrm{~m}$ in length. The site is located in a large open bay facing north, in the most wave exposed quadrant of the island throughout the year. Above high tide level, there is a $5 \mathrm{~m} \times 4 \mathrm{~m} \times 1.5 \mathrm{~m}$ deep concrete tank that retains freshwater from hydrothermal springs and overflows on to the rocky shore beneath it which consists mainly of pebbles and small to medium sized boulders, with larger boulders offshore. Hydrothermal hot springs of bubbling water can also be found along the shore among the pebbles at low tide, mainly on the eastern side of this stretch of shore.

Survey method

\section{Sea water}

A multiparameter water quality meter (HI 9828, Hannah Instruments, USA) was used to measure temperature, acidity (as $\mathrm{pH})$ and salinity. Measurements were made at three points around the bay at Ferraria (points a-c; Fig. 2)
Fig. 1 Map of São Miguel Island (Azores) showing location of two shores subjected to shallow water hydrothermal activity: (1) Ferraria $\left(37^{\circ} 51^{\prime} 27,745^{\prime \prime} \mathrm{N}\right.$; $\left.25^{\circ} 51^{\prime} 09,188^{\prime \prime} \mathrm{W}\right)$ and (2) Porto Formoso $\left(37^{\circ} 49^{\prime} 21,154^{\prime \prime} \mathrm{N}\right.$; $25^{\circ} 26^{\prime} 37,170^{\prime \prime} \mathrm{W}$ )

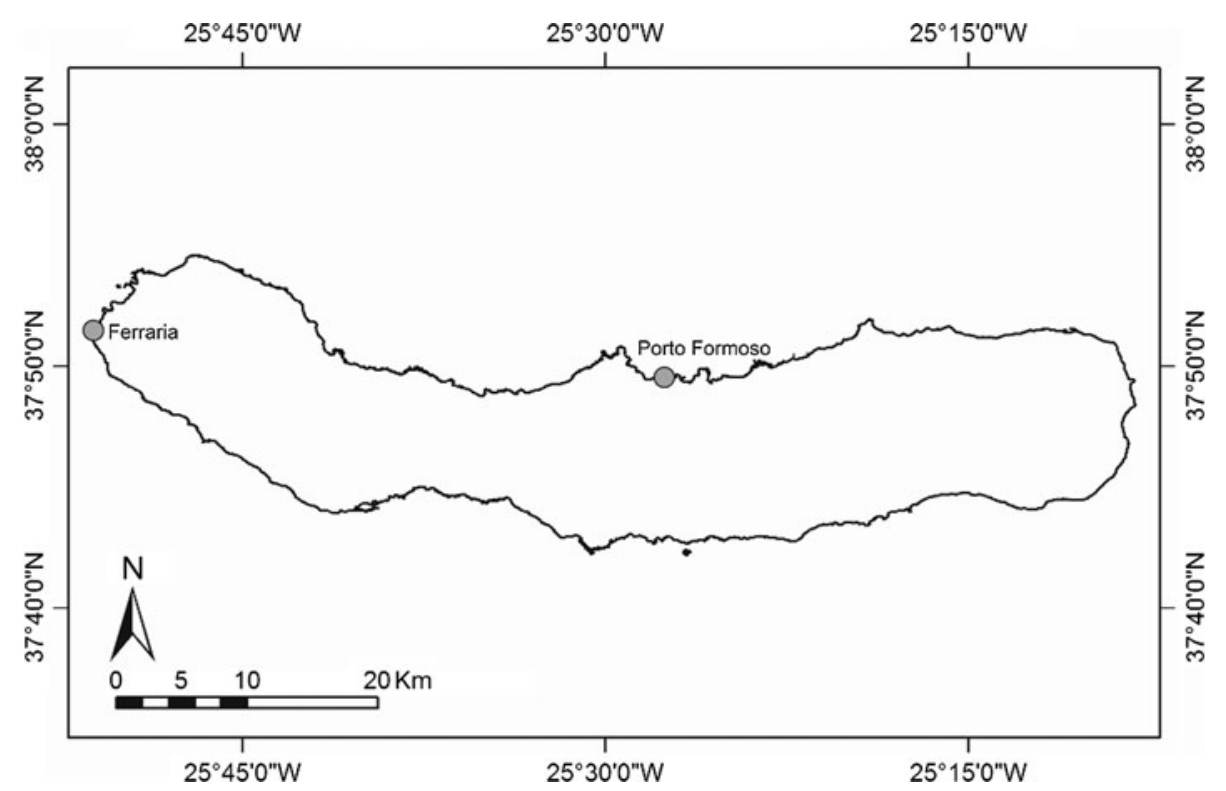


Fig. 2 Map of the bay at Ferraria showing zones for seaweed characterization $(A-D)$ and points of measurement for water temperature, $\mathrm{pH}$ and salinity $(a-c)$. The area around $c$ is where hydrothermal seepage is most intensely felt

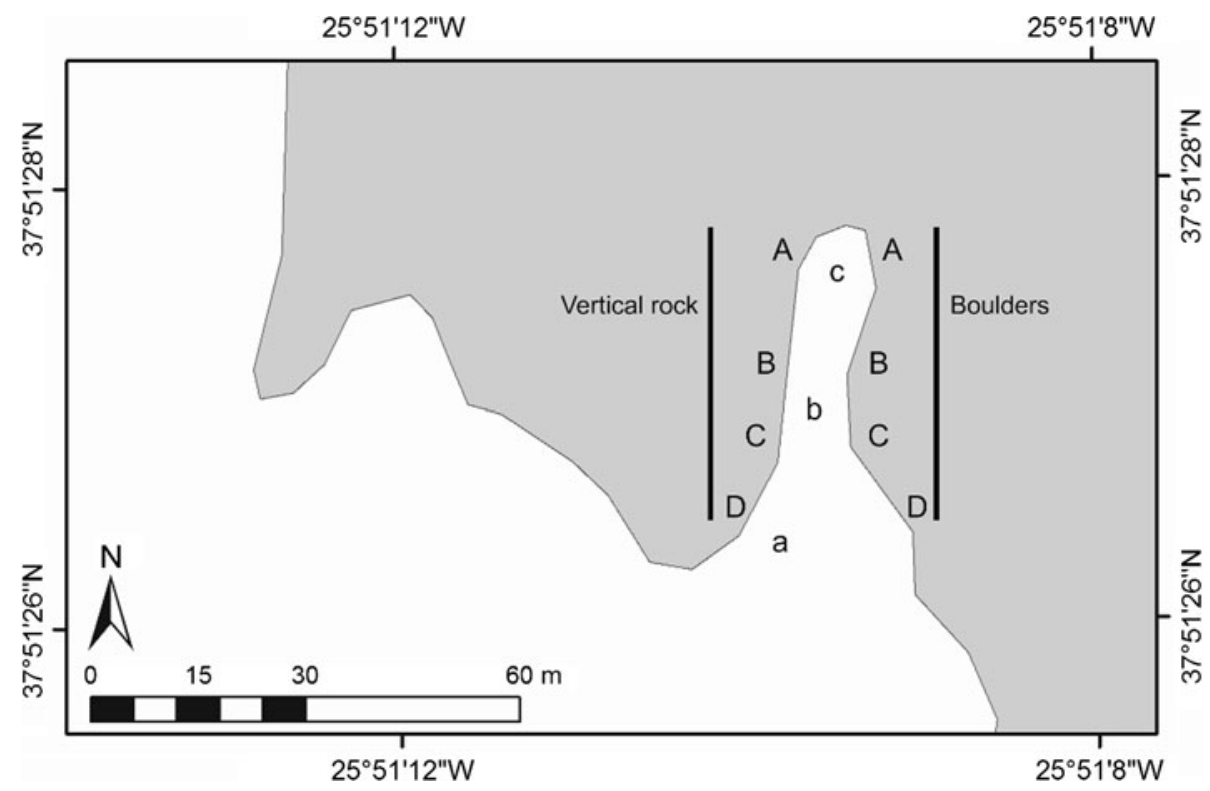

hourly over a period of $12 \mathrm{~h}$ to cover a whole tidal cycle in spring and winter on June 18, 2008, and on November 12, 2008. At Porto Formoso, measurements were made at three points along the shore (points a-c; Fig. 3) hourly for $12 \mathrm{~h}$ to cover a whole tidal cycle only in spring on July 8, 2008, due to increased access difficulty in winter.

\section{Seaweed communities}

At the time Ferraria was surveyed, slight differences were observed between the seaweed assemblages on each side of the bay, due to differing substrata, boulders and vertical bedrock wall. Furthermore, on both sides of the bay, preliminary observations indicated that there was a gradient in the proportions of different morphological groups of seaweeds as one moved further away from the "clean" water entrance toward the back of the bay. Therefore, sampling was carried out on four sections of the shore, of approximately $5 \mathrm{~m}$ in length, on each side of the bay to investigate differences in seaweed assemblages along a possible dilution gradient seawards from the inner bay (see Fig. 2).

Unlike Ferraria, the shore in Porto Formoso is uniform in terms of seaweed communities, which is not surprising given the uniformity of the main substratum type (small boulders and pebbles) and high wave exposure. However, as hydrothermal activity is more intense at the easternmost end of the bay sampling was carried out on three $5 \mathrm{~m}$ sections of the shore to record differences in seaweed assemblages along a gradient of possible hydrothermal intensity from east to west (see Fig. 3).
Fig. 3 Map of the Porto Formoso shore showing zones for seaweed characterization $(A-C)$ and points of measurement for water temperature, $\mathrm{pH}$ and salinity $(a-c)$

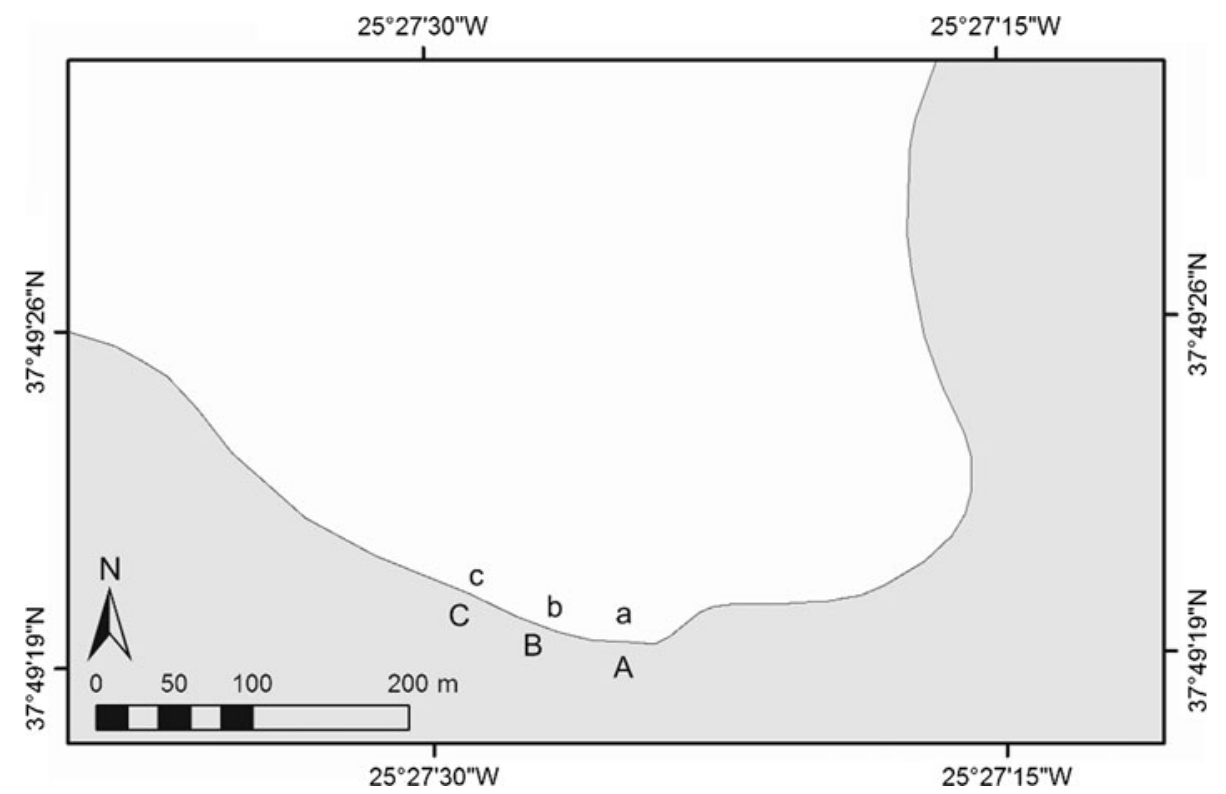


Tidal range in the Azores is maximum $1.8 \mathrm{~m}$, and the surveyed shores are steep resulting in a reduced intertidal area. Sampling was carried out at 3 different shore heights (near low water, mid-shore and top of shore) within $5 \mathrm{~m}$ sections of the surveyed shores. The presence of epilithic and epiphytic seaweeds was qualitatively recorded at the predicted time of low water. As no differences were found in species composition at the three shore levels, a decision was made to present composite data for each shore stretch. Seaweeds were identified to species level whenever possible in situ. Otherwise specimens were taken to the laboratory for identification. All names were cited according to the taxonomic nomenclature of Guiry and Guiry (2011).

\section{Data treatment}

The total number of species (species richness) and the proportions (R/B/G) of red (R; Rhodophyta), brown (B; Ochrophyta) and green (G; Chlorophyta) algal species on each section of the surveyed shores were extracted from the species lists.

All species were classified into two groups: ESG1-late successionals or perennials and ESG2-opportunists or annuals, according to Orfanidis et al. (2001), and the ratio between the number of perennial species and the number of annual species (ESG1/ESG2) calculated for each section of the surveyed shores, as suggested by Wilkinson and Wood (2003) to reflect shifts in seaweed community structure from reference pristine conditions. Species were also classified according to eight functional groups (FG1-unicellular and epiphytic, endophytic, epiphytic and endophytic forms; FG2-foliose, thin, membranous and sheet-like forms; FG3 - uniseriate filamentous forms; FG4-multiseriate and/or corticated filamentous forms; FG5-coarsely branched and highly corticated forms; FG6 - thick, leathery and cartilaginous forms; FG7-jointed calcareous forms; FG8 - crustose forms) based on the criteria adapted by Wells (2002) from Littler et al.(1983), and the relative proportions of each functional group calculated for each section of the surveyed shores.

\section{Results}

Sea water

Seawater temperatures in the Azores archipelago are seasonal with the highest values in late summer and the lowest values in early spring $\left(22.5^{\circ} \mathrm{C}\right.$ and $15.5^{\circ} \mathrm{C}$, respectively) and with high and constant salinity $( \pm 36 \%$ ) and acidity $( \pm 8.2)$ throughout the year (Hidrográfico 2000). Temperature, $\mathrm{pH}$ and salinity variations within the 12 -h periods at both shores are shown in Fig. 4 together with the tidal heights for the same days. The influence of hydrothermal water becomes greater as the tide goes out. On average, comparing sea water temperatures at low tide with those at high tide, at Ferraria, there is an increase in temperature of ca. $13{ }^{\circ} \mathrm{C}$ in spring and $23{ }^{\circ} \mathrm{C}$ in winter, and a decrease in ca. two units in $\mathrm{pH}$ and $4 \%$ in salinity at low tide both in spring and winter. The greater temperature variation in the winter survey is probably related to the substantially lower water level compared to that in spring $(0.25 \mathrm{~m}$ in November vs. $0.50 \mathrm{~m}$ in June). With the tide coming in (ascending part of the bold solid lines in Fig. 4), all parameter values go back to approximately "normal" sea water levels. Proximity to "clean" water input at the opening of Ferraria bay reduces the impact on temperature increase and $\mathrm{pH}$ decrease. This is evidenced by the greater temperature increase and $\mathrm{pH}$ decrease associated with the dotted lines, compared to the dashed and to the solid ones. This effect, however, is not evident in terms of salinity. As at Ferraria, the influence of hydrothermal water at Porto Formoso becomes obvious as the tide goes out, however, with less magnitude than at Ferraria. The average increase in temperature is of ca. $3{ }^{\circ} \mathrm{C}$ and the decrease in $\mathrm{pH}$ of 1 point and in salinity of $3 \%$. With the tide coming in (ascending part of the bold solid lines in Fig. 4), all parameter values go back to approximately "normal" sea water levels at all three sites. Although subjectively it had been expected to find greater hydrothermal activity at the eastern end of this shore (point a, Fig. 3), the intermediate point (point b, Fig. 3) showed the greatest hydrothermal impact with greatest variation in temperature, acidity and salinity.

\section{Seaweed communities}

The list of species that occur on both shores (given in "Appendix") is summarized in terms of major ecological and functional groups occurring at each survey station in Table 1. Given the dominant substratum types (boulders and bedrock) at Ferraria, this shore is very species poor relative to the average species richness reported by Wallenstein (2011) for the Azores $(43.9 \pm 19.4$; Mean $\pm \mathrm{SD})$. The average species richness does not differ between the boulder and the bedrock sides (14 and 15, respectively). However, the boulder side has on average a higher proportion of green $(0.41)$ and brown species $(0.26)$ and a lower proportion of red species $(0.34)$ compared to the bedrock wall $(0.24,0.16$ and $0.60)$, respectively. The average ESG ratio is also substantially lower for the boulder side (0.26) indicating a much smaller proportion of late successional species than for the bedrock wall (0.75). In terms of functional group composition, the boulder side shows on average higher proportions of thin foliose (FG2) and filamentous species (FG3 and FG4) and lower proportions of coarsely branched corticated species (FG5) than the bedrock wall. 

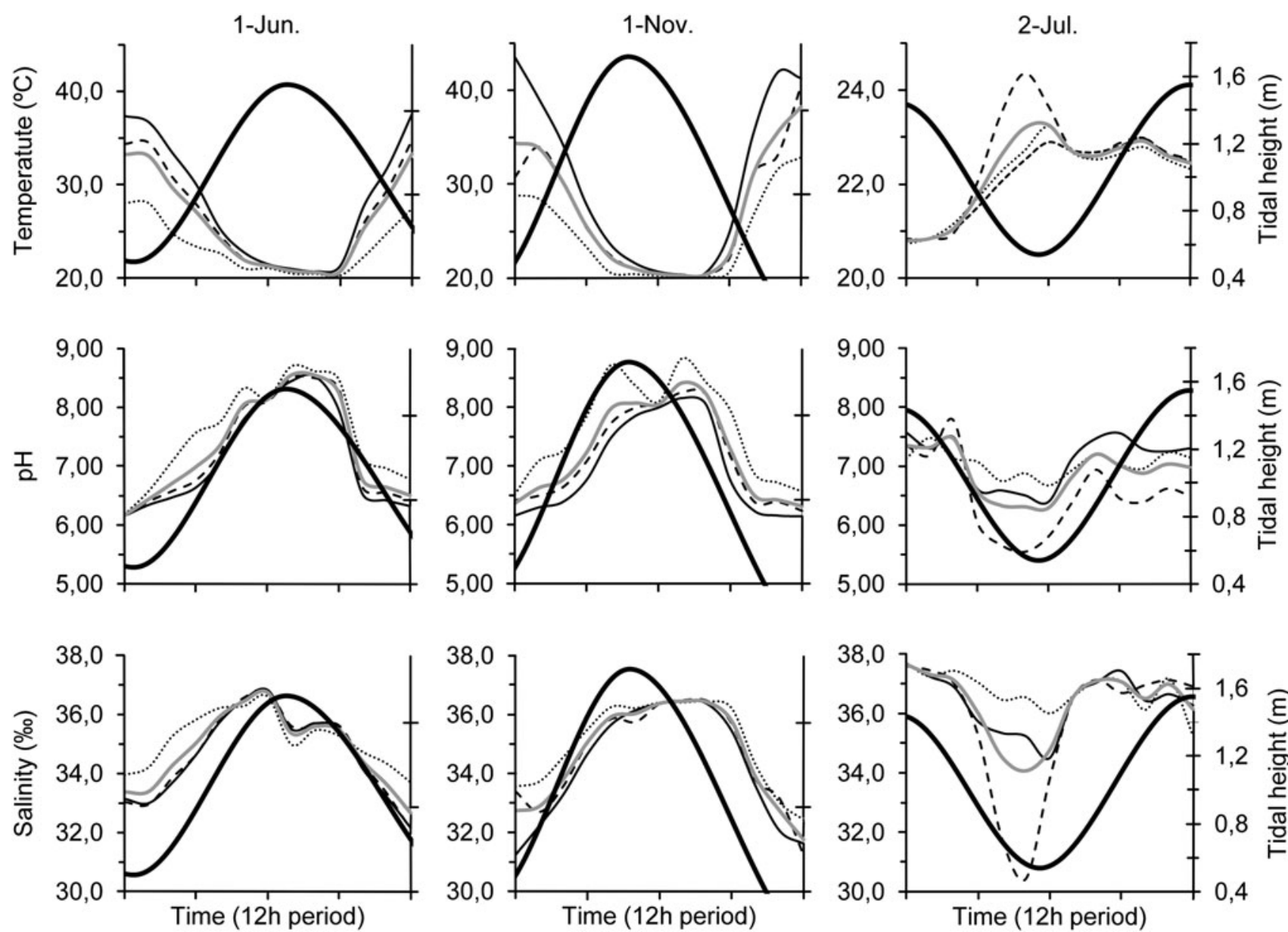

Fig. 4 Temperature, $\mathrm{pH}$ and salinity within the bay of Ferraria over a 12-h period in June 18, 2008 (1 Jun.), and in November 12, 2008 (1 Nov.), and at Porto Formoso over a 12-h period in July 8, 2008 ( 2 Jul.). Solid lines correspond to the point nearest to the opening of Ferraria bay (point c; Fig. 2) and easternmost point in Porto Formoso (point a; Fig. 3); dashed lines correspond to the intermediate distance

Along the gradient from the outermost to the innermost zone of Ferraria bay, species richness and the proportion of red species decreases, while the proportion of green species increases. On the boulder side, there is also a decreasing trend in the proportion of brown species, which is not evident on the bedrock wall side. Functional group composition showed the proportion of filamentous species to be highest and the proportion of coarsely branched corticated species (FG5) lowest at the innermost sections on both sides of the bay.

The shore in Porto Formoso is also relatively species poor compared to the average value reported for the Azores by Wallenstein (2011), which is not surprising for shores dominated by pebbles and small boulders. There is no pattern in terms of the features analyzed for each section of shore in Porto Formoso. In terms of $\mathrm{R} / \mathrm{B} / \mathrm{G}$ proportions, there is a greater similarity between sections B and C. However, section $\mathrm{B}$ is associated with a much lower ESG ratio (i.e., greater proportion of early successional species) and a higher from the opening of Ferraria bay (point b; Fig. 2) and intermediate point in Porto Formoso (point b; Fig. 3); dotted lines correspond to the point furthest away from the opening of Ferraria bay (point a; Fig. 2) and westernmost point in Porto Formoso (point c; Fig. 3); the gray line corresponds to the average value of the dotted, dashed and solid lines, and the bold solid line corresponds to the tidal height

proportion of filamentous species (FG3 and FG4) than sections $\mathrm{A}$ and $\mathrm{C}$.

\section{Discussion}

Despite the differences in shore aspect, dominant substratum and wave exposure between Ferraria and Porto Formoso, there is an obvious impact on sea water temperature, acidity and salinity at both sites caused by the input of hydrothermal water. The increase in temperature and acidity and the decrease in salinity are indicative of an input of hot and acidic freshwater, as evidenced by Carvalho et al. (2011). Furthermore, at both sites, there is evidence that the effect of hydrothermal water is subject to dissipation with distance from its source, tidal height and wave exposure. All these factors imply an increasing mixture of hydrothermal water and sea water, and a consequent dilution of the hydrothermal inputs. 
Table 1 Seaweed community features (species richness, proportions of Rhodophyta, Chlorophyta and Heterokontophyta, ESG ratio and functional group composition) for 8 sections of shore within the bay of Ferraria and 3 sections of shore in Porto Formoso

\begin{tabular}{|c|c|c|c|c|c|c|c|c|c|c|c|c|c|c|}
\hline \multirow{3}{*}{$\begin{array}{l}\text { Site } \\
\text { Substratum type } \\
\text { Shore section }\end{array}$} & \multicolumn{10}{|c|}{ Ferraria } & \multirow{2}{*}{\multicolumn{4}{|c|}{$\frac{\text { Porto Formoso }}{\text { Pebbles/small boulders }}$}} \\
\hline & \multicolumn{5}{|c|}{ Vertical bedrock } & \multicolumn{5}{|c|}{ Boulders } & & & & \\
\hline & A & B & $\mathrm{C}$ & $\mathrm{D}$ & Average & A & B & $\mathrm{C}$ & $\mathrm{D}$ & Average & A & B & $\mathrm{C}$ & Average \\
\hline Species richness & 11 & 11 & 18 & 19 & 14.8 & 9 & 16 & 16 & 14 & 13.8 & 10 & 18 & 19 & 15.7 \\
\hline \multicolumn{15}{|l|}{ Proportions } \\
\hline Rhodophyta & 0.45 & 0.64 & 0.61 & 0.68 & 0.60 & 0.22 & 0.38 & 0.38 & 0.36 & 0.34 & 0.60 & 0.61 & 0.53 & 0.58 \\
\hline Chlorophyta & 0.36 & 0.18 & 0.22 & 0.21 & 0.24 & 0.67 & 0.38 & 0.31 & 0.29 & 0.41 & 0.20 & 0.17 & 0.21 & 0.19 \\
\hline Heterokontophyta & 0.18 & 0.18 & 0.17 & 0.11 & 0.16 & 0.11 & 0.25 & 0.31 & 0.36 & 0.26 & 0.20 & 0.22 & 0.26 & 0.23 \\
\hline ESG ratio & 0.57 & 0.83 & 1.00 & 0.58 & 0.75 & 0.29 & 0.33 & 0.14 & 0.27 & 0.26 & 1.50 & 0.80 & 2.80 & 1.70 \\
\hline \multicolumn{15}{|l|}{ Proportions } \\
\hline FG1 & 0 & 0 & 0 & 0 & 0.00 & 0 & 0 & 0.06 & 0 & 0.02 & 0 & 0 & 0 & 0.00 \\
\hline FG2 & 0.27 & 0.27 & 0.28 & 0.32 & 0.29 & 0.33 & 0.38 & 0.31 & 0.29 & 0.33 & 0.10 & 0.06 & 0.05 & 0.07 \\
\hline FG3 & 0.36 & 0.18 & 0.22 & 0.16 & 0.23 & 0.44 & 0.19 & 0.25 & 0.36 & 0.31 & 0 & 0.22 & 0.05 & 0.09 \\
\hline FG4 & 0.09 & 0.09 & 0.06 & 0.05 & 0.07 & 0.11 & 0.13 & 0.19 & 0.07 & 0.13 & 0.40 & 0.39 & 0.26 & 0.35 \\
\hline FG5 & 0.27 & 0.45 & 0.44 & 0.47 & 0.41 & 0.11 & 0.25 & 0.19 & 0.29 & 0.21 & 0.40 & 0.22 & 0.47 & 0.36 \\
\hline FG6 & 0 & 0 & 0 & 0 & 0.00 & 0 & 0 & 0 & 0 & 0.00 & 0.10 & 0.06 & 0.11 & 0.09 \\
\hline FG7 & 0 & 0 & 0 & 0 & 0.00 & 0 & 0 & 0 & 0 & 0.00 & 0 & 0 & 0 & 0.00 \\
\hline FG8 & 0 & 0 & 0 & 0 & 0.00 & 0 & 0.06 & 0 & 0 & 0.02 & 0 & 0.06 & 0.05 & 0.04 \\
\hline
\end{tabular}

Legend for shore section according to Figs. 2 and 3

De Biasi et al. (2004) note that the effects of hydrothermalism in shallow water are complex, and particularly subtle on rocky substratum communities. Other studies (e.g., Dando et al. 1991; Kamenev et al. 1993) provide evidence that only in areas with reduced water motion, for example, closed bays, does vent activity induce significant changes in composition and distribution of benthic communities. This is the case at Ferraria which contrasts with the highly hydrodynamic site in Porto Formoso.

Despite these differences between the two sites, the innermost part of Ferraria bay (zone A; see Fig. 2) and the middle zone of the shore in Porto Formoso (section B; see Fig. 3) share two features in common in terms of seaweed communities: (1) a higher proportion of early successional species (low ESG ratios) and (2) higher proportions of filamentous species (FG3 and FG4), when compared with the adjacent areas. The impact on the algal communities of the hydrothermal input is also greater in sea water surrounding these sections of shore due to their proximity to its source, and it is thus possible to establish a probable causal relationship between shallow water hydrothermal activity and the type of seaweed communities that occur on the shores affected by it. A typical shore in the Azores, as seen in the adjacent small bay of Ferraria, is largely characterized by thick algal turf communities, the dominant species being coarsely branched, highly corticated seaweeds (species richness of $44 \pm 20$; red, green and brown proportions of $\mathrm{R}-48 \pm 0.09 / \mathrm{G}-$ $0.24 \pm 0.10 / \mathrm{B}-0.28 \pm 0.07 ; \quad$ and functional group proportions of $\mathrm{FG} 1-0.10 \pm 0.05 ; \quad \mathrm{FG} 2-0.17 \pm 0.06$;
FG3 $-0.19 \pm 0.06$; FG4 $-0.15 \pm 0.04$; FG5 $-0.18 \pm 0.06$; FG6-0.13 $\pm 0.04 ;$ FG7-0.01 \pm 0.01 ; FG8 $-0.07 \pm 0.05$; see Wallenstein et al. 2008). By contrast at Ferraria and Porto Formoso, severely affected by shallow water hydrothermal activity, seaweed communities tend to be less species rich and have a disproportionally large number of early successional species particularly on stable substrata such as large boulders or bedrock. Porzio et al. (2011) and Johnson et al. (2011) refer to a decrease in species richness at sites with increased acidity. However, Porzio et al. (2011) describe an associated reduction in the dominance of turf algae that are replaced by more morphologically complex erect species. This tendency is opposite to that observed in Ferraria and Porto Formoso with coarsely branched turf-forming species being replaced with turf-forming, filamentous species. Connell and Russell (2010) demonstrated that turf cover increased considerably when increased $\mathrm{CO}_{2}$ levels were combined with elevated temperatures, while Kleypas et al. (2006) showed that turfs declined in diversity and abundance along a $\mathrm{pH}$ gradient, despite the fact that these are usually considered opportunistic species that are resistant to ocean acidification. According to Hall-Spencer et al. (2008), some species that are usually considered opportunistic have been proved to be resistant to naturally high amounts of $\mathrm{pCO}_{2}$. The results of the present study are in accordance with such evidence, whereby lower diversity and increased opportunistic species proportion are associated with increased temperature and acidity. The total absence of coralline algae at both study sites, where hydrothermal effects increase acidity, is in accordance with Porzio et al. (2011) who 
reported total absence of calcareous species at mean $\mathrm{pH}$ 6.7. Such evidence is a direct result of the destructive effect of $\mathrm{pH}$ on the calcareous skeleton of coralline algae as shown by Couto et al. (2010), Jokiel et al. (2008) and Martin and Gattuso (2009).

There is a remarkable resemblance between seaweed community features on the shores here described and those described by Woolsey and Wilkinson (2007), on a shore affected by acid mine drainage in the UK. Seaweeds collected under such different scenarios exhibit similar increased metal accumulation (Woolsey and Wilkinson 2007; Wallenstein et al. 2009; Wallenstein 2011). In both studies, intertidal communities are affected by acidic, metal-enriched, freshwater inputs (Carvalho et al. 2011; Woolsey and Wilkinson 2007). In both cases, the input sources are localized and their effects in sea water dissipate due to dilution caused by the increasing influence of clean sea water and consequently the magnitude of their impacts on seaweed communities-lower species richness and a large proportion of early successional species in both studies-decreases with increasing distance from the input source. Such effects at the community level are a reflection of processes that occur at the species, cellular and/or physiological levels, as evidenced in studies showing that growth and reproduction are affected by temperature, acidity and enriched metals in different ways from species to species (e.g., Blinks 1963; Kangwe et al. 2001; Kuffner et al. 2008; Porzio et al. 2011).

Table 2 Species presence (1)/absence (0) at 8 sections of shore with in the bay of Ferraria and 3 sections of shore in Porto Formoso [Opport Opportunist species, ESG ecological status group (ESG1-late successional; ESG2 - early successional), $F G$ functional group (FG1unicellular and epiphytic, endophytic, epiphytic and endophytic forms;
Although shallow water hydrothermal activity on intertidal seaweed communities is localized in the Azores, the present study shows that such effects are comparable to those caused by pollution of anthropogenic origin. Furthermore, the studies by Wallenstein et al. (2009) and Couto et al. (2010) provide evidence that seaweeds are affected not only at the community level, but also at the structural and cellular levels. It is therefore necessary to evaluate the impacts of pollution at different complementary levels, taking into account factors such as salinity, temperature and $\mathrm{pH}$ that affect seaweed growth and reproduction (Phillips 1990). The increased temperature and acidity and reduced salinity that characterize sea water around hydrothermal vents provide suitable conditions for studies on the effects of chemical pollution by heavy metals within the context of generalized concerns about global warming and ocean acidification (e.g., Martin et al. 2008; Porzio et al. 2011).

Acknowledgments This work was funded by CIRN (Centro de Investigação de Recursos Naturais; University of the Azores), Francisco Wallenstein was supported by a $\mathrm{PhD}$ grant from Fundação para a Ciência e Tecnologia (SFRH/BD/27466/2006). Ruben Couto was supported by a $\mathrm{PhD}$ grant from the Regional Government of Azores (DRCT-M3.1.1/I/014A/2005). The sampling procedures of the present study comply with the current laws of Portugal.

\section{Appendix}

See Table 2.

FG2 - foliose, thin, membranous and sheet-like forms; FG3-uniseriate filamentous forms; FG4 - multiseriate and/or corticated filamentous forms; FG5 - coarsely branched and highly corticated forms; FG6thick, leathery and cartilaginous forms; FG7-jointed calcareous forms; FG8 - crustose forms)]

\begin{tabular}{|c|c|c|c|c|c|c|c|c|c|c|c|c|c|c|}
\hline \multirow[b]{3}{*}{ Rhodophyta } & \multirow[t]{3}{*}{ Oport } & \multirow[t]{3}{*}{ ESG } & \multirow[t]{3}{*}{ FG } & \multicolumn{8}{|c|}{ Ferraria } & \multirow{2}{*}{\multicolumn{3}{|c|}{$\frac{\text { P Formoso }}{\text { Boulders/pebbles }}$}} \\
\hline & & & & \multicolumn{4}{|c|}{ Vertical bedrock } & \multicolumn{4}{|c|}{ Boulders } & & & \\
\hline & & & & A & B & $\mathrm{C}$ & $\mathrm{D}$ & A & B & $\mathrm{C}$ & $\mathrm{D}$ & A & $\mathrm{B}$ & $\mathrm{C}$ \\
\hline Acrosorium venulosum & 0 & 2 & 2 & 0 & 0 & 0 & 1 & 0 & 0 & 0 & 0 & 0 & 0 & 0 \\
\hline Aglaothamnion sp. & 0 & 2 & 3 & 0 & 0 & 0 & 0 & 0 & 0 & 0 & 0 & 0 & 1 & 0 \\
\hline Antithamnion decipiens & 0 & 2 & 3 & 0 & 0 & 0 & 0 & 0 & 0 & 0 & 0 & 0 & 1 & 0 \\
\hline Callithamnion corymbosum & 0 & 2 & 3 & 1 & 1 & 1 & 1 & 0 & 1 & 1 & 1 & 0 & 0 & 0 \\
\hline Callithamnion sp. & 0 & 2 & 3 & 0 & 0 & 0 & 1 & 0 & 0 & 0 & 0 & 0 & 0 & 0 \\
\hline Callithamnion tetragonum & 0 & 2 & 3 & 0 & 0 & 0 & 1 & 0 & 0 & 0 & 0 & 0 & 0 & 0 \\
\hline Caulacanthus ustulatus & 0 & 1 & 5 & 0 & 0 & 1 & 1 & 0 & 0 & 0 & 0 & 0 & 0 & 0 \\
\hline Centroceras clavulatum & 0 & 2 & 4 & 0 & 0 & 0 & 0 & 0 & 1 & 0 & 0 & 0 & 0 & 0 \\
\hline Ceramium ciliatum & 0 & 2 & 4 & 0 & 0 & 0 & 0 & 0 & 0 & 0 & 0 & 0 & 1 & 0 \\
\hline Ceramium diaphanum & 0 & 2 & 4 & 0 & 1 & 0 & 1 & 0 & 0 & 0 & 0 & 0 & 1 & 1 \\
\hline Ceramium rubrum & 0 & 2 & 4 & 0 & 0 & 0 & 0 & 0 & 0 & 0 & 0 & 1 & 1 & 0 \\
\hline Chondracanthus acicularis & 0 & 1 & 5 & 0 & 0 & 1 & 1 & 0 & 0 & 0 & 0 & 1 & 1 & 1 \\
\hline Ctenosiphonia hypnoides & 0 & 1 & 5 & 0 & 0 & 0 & 0 & 0 & 0 & 0 & 0 & 0 & 0 & 1 \\
\hline Diplothamnion jolyi & 0 & 2 & 3 & 0 & 0 & 0 & 0 & 0 & 0 & 0 & 0 & 0 & 1 & 0 \\
\hline Falkenbergia rufolanosa phase & 0 & 2 & 4 & 0 & 0 & 0 & 0 & 0 & 0 & 0 & 0 & 1 & 1 & 1 \\
\hline
\end{tabular}


Table 2 continued

\begin{tabular}{|c|c|c|c|c|c|c|c|c|c|c|c|c|c|c|}
\hline \multirow[b]{3}{*}{ Gelidium microdon } & \multirow{3}{*}{$\begin{array}{l}\text { Oport } \\
0\end{array}$} & \multirow{3}{*}{$\begin{array}{l}\text { ESG } \\
1\end{array}$} & \multirow{3}{*}{$\begin{array}{l}\text { FG } \\
5\end{array}$} & \multicolumn{8}{|c|}{ Ferraria } & \multirow{2}{*}{\multicolumn{3}{|c|}{$\frac{\text { P Formoso }}{\text { Boulders/pebbles }}$}} \\
\hline & & & & \multicolumn{4}{|c|}{ Vertical bedrock } & \multicolumn{4}{|c|}{ Boulders } & & & \\
\hline & & & & 1 & 1 & 1 & 1 & 0 & 0 & 0 & 0 & 0 & 0 & 0 \\
\hline Gelidium pusillum & 0 & 1 & 5 & 0 & 1 & 1 & 1 & 1 & 1 & 0 & 1 & 1 & 1 & 1 \\
\hline Gymnogongrus crenulatus & 0 & 1 & 5 & 1 & 1 & 1 & 1 & 0 & 1 & 1 & 0 & 1 & 0 & 1 \\
\hline Herposiphonia secunda & 0 & 1 & 5 & 1 & 0 & 1 & 1 & 0 & 0 & 0 & 0 & 0 & 0 & 0 \\
\hline Lophosiphonia reptabunda & 0 & 1 & 5 & 0 & 0 & 0 & 0 & 0 & 0 & 0 & 1 & 0 & 0 & 1 \\
\hline Nitophyllum punctatum & 0 & 2 & 2 & 0 & 0 & 1 & 0 & 0 & 0 & 0 & 0 & 0 & 0 & 0 \\
\hline Palisada poiteaui & 0 & 1 & 5 & 0 & 0 & 0 & 0 & 0 & 0 & 0 & 0 & 0 & 1 & 1 \\
\hline Phyllophora gelidioides & 0 & 1 & 5 & 0 & 1 & 0 & 0 & 0 & 0 & 0 & 0 & 0 & 0 & 0 \\
\hline Polysiphonia sp. & 0 & 2 & 4 & 0 & 0 & 0 & 0 & 1 & 1 & 1 & 0 & 0 & 1 & 1 \\
\hline Polysiphonia sphacelaria & 0 & 2 & 4 & 0 & 0 & 0 & 0 & 0 & 0 & 1 & 0 & 0 & 0 & 0 \\
\hline Polysiphonia stricta & 0 & 2 & 4 & 1 & 0 & 1 & 0 & 0 & 0 & 1 & 1 & 1 & 0 & 0 \\
\hline Porphyra sp. & 1 & 2 & 2 & 0 & 1 & 1 & 1 & 0 & 1 & 1 & 1 & 0 & 0 & 0 \\
\hline Rhodymenia holmesii & 0 & 1 & 5 & 0 & 0 & 1 & 1 & 0 & 0 & 0 & 0 & 0 & 0 & 0 \\
\hline Symphyocladia marchantioides & 0 & 1 & 8 & 0 & 0 & 0 & 0 & 0 & 0 & 0 & 0 & 0 & 0 & 1 \\
\hline Total & & & & 5 & 7 & 11 & 13 & 2 & 6 & 6 & 5 & 6 & 11 & 10 \\
\hline \multicolumn{15}{|l|}{ Heterokontohyta } \\
\hline Cladostephus spongiosus & 0 & 1 & 4 & 0 & 0 & 0 & 0 & 0 & 0 & 0 & 0 & 0 & 1 & 1 \\
\hline Colpomenia sinuosa & 0 & 1 & 5 & 0 & 0 & 0 & 0 & 0 & 0 & 0 & 0 & 0 & 0 & 1 \\
\hline Brown crust & 0 & 1 & 8 & 0 & 0 & 0 & 0 & 0 & 1 & 0 & 0 & 0 & 1 & 0 \\
\hline Cystoseira abies-marina & 0 & 1 & 6 & 0 & 0 & 0 & 0 & 0 & 0 & 0 & 0 & 0 & 0 & 1 \\
\hline Ectocarpus fasciculatus & 1 & 2 & 3 & 0 & 0 & 0 & 0 & 0 & 0 & 0 & 1 & 0 & 0 & 0 \\
\hline Ectocarpus siliculosus & 1 & 2 & 3 & 1 & 0 & 0 & 0 & 0 & 0 & 1 & 1 & 0 & 0 & 0 \\
\hline Endarachne binghamiae & 0 & 2 & 5 & 0 & 1 & 1 & 1 & 0 & 1 & 1 & 1 & 0 & 0 & 0 \\
\hline Hecatonema terminale & 0 & 2 & 1 & 0 & 0 & 0 & 0 & 0 & 0 & 1 & 0 & 0 & 0 & 0 \\
\hline Sargassum cymosum & 0 & 1 & 6 & 0 & 0 & 0 & 0 & 0 & 0 & 0 & 0 & 1 & 1 & 0 \\
\hline Sargassum furcatum & 0 & 1 & 6 & 0 & 0 & 0 & 0 & 0 & 0 & 0 & 0 & 0 & 0 & 1 \\
\hline Scytosiphon lomentaria & 0 & 2 & 5 & 0 & 0 & 0 & 1 & 0 & 1 & 1 & 1 & 0 & 0 & 0 \\
\hline Sphacelaria rigidula & 0 & 1 & 3 & 0 & 1 & 1 & 0 & 1 & 1 & 1 & 1 & 0 & 0 & 0 \\
\hline Sphacelaria sp. & 0 & 1 & 3 & 1 & 0 & 1 & 0 & 0 & 0 & 0 & 0 & 0 & 0 & 0 \\
\hline Stypocaulon scoparium & 0 & 1 & 4 & 0 & 0 & 0 & 0 & 0 & 0 & 0 & 0 & 1 & 1 & 1 \\
\hline Total & & & & 2 & 2 & 3 & 2 & 1 & 4 & 5 & 5 & 2 & 4 & 5 \\
\hline \multicolumn{15}{|l|}{ Chlorophyta } \\
\hline Blidingia minima & 1 & 2 & 2 & 1 & 0 & 0 & 0 & 0 & 0 & 0 & 0 & 0 & 0 & 0 \\
\hline Bryopsis cupressina & 0 & 2 & 2 & 0 & 0 & 1 & 1 & 0 & 0 & 0 & 0 & 0 & 0 & 0 \\
\hline Bryopsis plumosa & 0 & 2 & 2 & 0 & 0 & 0 & 0 & 0 & 1 & 0 & 0 & 0 & 0 & 0 \\
\hline Chaetomorpha aerea & 1 & 2 & 3 & 0 & 0 & 0 & 0 & 1 & 1 & 0 & 0 & 0 & 1 & 1 \\
\hline Cladophora albida & 0 & 2 & 3 & 0 & 0 & 1 & 0 & 1 & 0 & 0 & 0 & 0 & 0 & 0 \\
\hline Cladophora conferta & 0 & 2 & 3 & 1 & 0 & 0 & 0 & 0 & 0 & 0 & 0 & 0 & 0 & 0 \\
\hline Cladophora laetervirens & 0 & 2 & 3 & 0 & 0 & 0 & 0 & 1 & 0 & 1 & 1 & 0 & 0 & 0 \\
\hline Codium adhaerens & 0 & 1 & 5 & 0 & 0 & 0 & 0 & 0 & 0 & 0 & 0 & 1 & 1 & 1 \\
\hline Codium fragile & 0 & 1 & 5 & 0 & 0 & 0 & 0 & 0 & 0 & 0 & 0 & 0 & 0 & 1 \\
\hline Ulva compressa & 1 & 2 & 2 & 0 & 1 & 0 & 0 & 1 & 1 & 1 & 1 & 1 & 0 & 0 \\
\hline Ulva intestinalis & 1 & 2 & 2 & 1 & 0 & 1 & 1 & 1 & 1 & 1 & 1 & 0 & 0 & 1 \\
\hline Ulva prolifera & 1 & 2 & 2 & 0 & 0 & 0 & 1 & 1 & 1 & 1 & 0 & 0 & 1 & 0 \\
\hline Ulva rigida & 1 & 2 & 2 & 1 & 1 & 1 & 1 & 0 & 1 & 1 & 1 & 0 & 0 & 0 \\
\hline \multirow[t]{2}{*}{ Total } & & & & 4 & 2 & 4 & 4 & 6 & 6 & 5 & 4 & 2 & 3 & 4 \\
\hline & & & & 11 & 11 & 18 & 19 & 9 & 16 & 16 & 14 & 10 & 18 & 19 \\
\hline
\end{tabular}

Legend for shore section according to Figs. 2 and 3 


\section{References}

Blinks LR (1963) The effect of $\mathrm{pH}$ upon the photosynthesis of littoral marine algae. Protoplasma 57:126-136

Cardigos F, Colaço A, Dando PR, Ávila SP, Sarradim PM, Tempera F, Conceição P, Pascoal A, Santos RS (2005) Shallow water hydrothermal vent field fluids and communities of the D. João de Castro Seamount (Azores). Chem Geol 224:153-168

Carvalho MR, Mateus A, Nunes JC, Carvalho JM (2011) Chemistry of the Ferraria thermal water, S. Miguel Island, Azores: mixing and precipitation processes. Environ Earth Sci 64:539-547

Colaço A, Raghukumar C, Mohandass C (2006) Effect of shallowwater venting in Azores on a few marine biota. Cahiers Biol Mar 47:359-364

Connell SD, Russell BD (2010) The direct effects of increasing $\mathrm{CO}_{2}$ and temperature on non-calcifying organisms: increasing the potential for phase shifts in kelp forests. Proc R Soc B 277:1409-1415

Couto RP, Neto AI, Rodrigues AS (2010) Metal concentration and structural changes in Corallina elongata (Corallinales, Rhodophyta) from hydrothermal vents. Mar Pollut Bull 60:509-514

Cruz JV, França Z (2006) Hydrogeochemistry of thermal and mineral water springs of the Azores archipelago (Portugal). J Volcanol Geotherm Res 151:382-398

Dando PR, Austen MC, Burke RAJ, Kendall MA, Kennicut MV, Judd AG, Moore DC, O’Hara SCM, Schmaljohann R, Southward AJ (1991) Ecology of a North Sea pockmark with an active methane seep. Mar Ecol Prog Ser 70:49-63

De Biasi AM, Aliani S (2003) Shallow-water hydrothermal vents in the Mediterranean sea: stepping stones for Lessepsian migration? Hydrobiologia 503:37-44

De Biasi AM, Bianchi CN, Aliani S, Cocito S, Peirano A, Dando PR, Morri C (2004) Epibenthic communities in a marine shallow area with hydrothermal vents (Milos Island, Aegean Sea). Chem Ecol 20:89-105

Elliott M, Cutts ND (2004) Marine habitats: loss and gain, mitigation and compensation. Mar Pollut Bull 49:671-674

Guiry MD, Guiry GM (2011) AlgaeBase. http://www.algaebase.org. Accessed continuously during the study

Hall-Spencer JM, Rodolfo-Metalpa R, Martin S, Ransome E, Fine M, Turner SM, Rowley SJ, Tedesco D, Buia MC (2008) Volcanic carbon dioxide vents show ecosystem effects of ocean acidification. Nature 454:96-99

Hidrográfico I (2000) Roteiro da Costa de Portugal-Arquipélago dos Açores. PUB. (N)-IH-128-SN, Lisboa

Johnson V, Brownlee C, Rickaby R, Graziano M, Milazzo M, HallSpencer J (2011) Responses of marine benthic microalgae to elevated $\mathrm{CO}_{2}$. Mar Biol. doi:10.1007/s00227-011-1840-2

Jokiel PL, Rodgers KS, Kuffner IB, Andersson AJ, Cox EF, Mackenzie FT (2008) Ocean acidification and calcifying reef organisms: a mesocosm investigation. Coral Reefs 27(3):473-483

Kamenev GM, Fadeev VI, Selin NI, Tarasov VG (1993) Composition and distribution of macro and meiobenthos around sublittoral hydrothermal vents in the Bay of Plenty, New Zealand. N Z J Mar Fresh 27:407-418

Kangwe JW, Hellblom F, Semesi AK, Mtolera MSP, Bjork M (2001) Heavy metal inhibition of calcification and photosynthetic rates of the geniculate calcareous alga Amphiroa tribulus. Mar Sci Dev Tanzan East Afr 1:147-157
Kleypas JA, Feely RA, Fabry VJ, Langdon C, Sabine CL, Robbins LL (2006) Impacts of ocean acidification on coral reefs and other marine calcifiers: a guide for future research. In: Report of a workshop held 18-20 April 2005, St Petersburg, FL, sponsored by NSF, NOAA, and the US Geological Survey, St. Petersburg, FL

Kuffner IB, Andersson AJ, Jokiel PL, Rodgers KS, Mackenzie FT (2008) Decreased abundance of crustose coralline algae due to ocean acidification. Nat Geosci 1:114-117

Littler MM, Littler DS, Taylor PR (1983) Evolutionary strategies in a tropical barrier reef system: functional-form groups of marine macroalgae. J Phycol 19:229-237

Martin S, Gattuso JP (2009) Response of Mediterranean coralline algae to ocean acidification and elevated temperature. Glob Change Biol 15:2089-2100

Martin S, Rodolfo-Metalpa R, Ransome E, Rowley S, Buia MC, Gattuso JP, Hall-Spencer JM (2008) Effects of naturally acidified seawater on seagrass calcareous epibionts. Biol Lett UK 4:689-692

Orfanidis S, Panayotidis P, Stamatis N (2001) Ecological evaluation of transitional and coastal waters: a marine benthic macrophytesbased model. Mediterr Mar Sci 2:45-65

Phillips DJH (1990) Use of macroalgae and invertebrates as monitors of metal levels in estuarine and coastal waters. In: Furness RW, Rainbow PS (eds) Heavy metals in the marine environment. CRC Press, Boca Raton, pp 82-89

Porzio L, Buia MC, Hall-Spencer JM (2011) Effects of ocean acidification on macroalgal communities. J Exp Biol Ecol 400:278-287

Sartoni G, De Biasi AM (1999) A survey of the marine algae of Milos Island, Greece. Cryptogam Algol 20:271-283

Von Damm KL (1990) Seafloor hydrothermal activity: black smoker chemistry and chimneys. Annu Rev Earth Planet Sci 18:173-204

Wallenstein FM (2011) Rocky shore macroalgae communities of the Azores (Portugal) and the British Isles: a comparison for the development of ecological quality assessment tools. PhD Dissertation. Heriot-Watt University, Edinburgh

Wallenstein FM, Neto AI, Álvaro NV, Santos CI (2008) Algae-based biotopes of the Azores (Portugal): spatial and seasonal variation. Aquat Ecol 42:547-559

Wallenstein FM, Couto RP, Amaral AS, Wilkinson M, Neto AI, Rodrigues AS (2009) Baseline metal concentrations in marine algae from São Miguel (Azores) under different ecological conditions-urban proximity and shallow water hydrothermal activity. Mar Pollut Bull 58:424-455

Wells EC (2002) Seaweed species biodiversity on intertidal rocky seashores in the British Isles. PhD Dissertation. Heriot-Watt University, Edinburgh

Wilkinson M, 1Wood P (2003) Type-specific reference conditions for macroalgae and angiosperms in Scottish transitional and coastal waters. Report to Scottish Environment Protection Agency from School of Life Sciences, Heriot-Watt University. SEPA report ref. $230 / 4136$

Woolsey S, Wilkinson M (2007) Localized field effects of drainage water from abandoned coal mines on intertidal rocky shore seaweeds at St. Monans, Scotland. J Mar Biol Assoc UK 87:659-665 